Periodica Polytechnica Architecture, 51(2), pp. 178-188, 2020

\title{
Interface of the Natural Ventilation Systems with Building Management Systems
}

\author{
Ilker Karadag ${ }^{1 *}$, Aysem Berrin Cakmakli² \\ 1 Department of Architecture, Faculty of Fine Arts, Design and Architecture, Manisa Celal Bayar University, 45040 Manisa, \\ Sehzadeler, Halil Erdogan Street, Turkey \\ 2 Department of Architecture, Faculty of Architecture, Middle East Technical University, 06800 Ankara, Çankaya, 1 Dumlupınar \\ Boulevard, Turkey \\ *Corresponding author, e-mail: ilker.karadag@cbu.edu.tr
}

Received: 06 February 2020, Accepted: 26 August 2020, Published online: 02 November 2020

\begin{abstract}
The vertical city is increasingly being seen as the most viable solution for many urban centers. However, being vertical means constructing tall buildings which imply a large amount of energy requirement mostly due to the mechanical ventilation systems. Replacing these systems with natural ventilation is of importance on the way of achieving sustainable buildings and cities. However, there are many challenges in incorporating natural ventilation systems into tall office buildings. Because, having a far distance from the ground levels, tall buildings are exposed to turbulent and unstable wind conditions. Therefore, advanced technical systems to monitor/control a tall building is required even though natural ventilation is mostly considered a passive, low technological approach to condition a building. These systems utilize sensors to measure internal environmental conditions and external conditions of air temperature, humidity, wind velocity, and rain to utilize passive or active modes, based on the data received. To integrate such systems, in most cases, a hybrid approach is required to fill the gap between the natural and mechanical ventilation systems. Since, climate conditions may not be suitable for solely depending on natural ventilation throughout the year, using mechanical ventilation systems as a back-up to natural ventilation is mostly required. Based on this approach, this study presents advanced natural ventilation strategies of a number of buildings integrating Building Management Systems. Throughout the study, it is intended to guide further researches on natural ventilation and consequently to contribute to the environmental quality of urban areas and smart sustainable development of the cities.
\end{abstract}

\section{Keywords}

building aerodynamics, natural ventilation, building management system, wind efficient design, smart buildings

\section{Introduction}

Tall buildings are commonly seen forms of urban settlements and they involve too many functions with plenty of spaces on a low base area with using advantageous of having too many floors. Besides, they have important impacts on local wind characteristics around the near-field urban area. Strong winds are usually accelerated throughout the building height due to the logarithmic profile of the approaching airflow. In urban areas, with increasing altitudes from the ground, wind speed increases since there are fewer obstructions (roughness) to prevent airflow via friction. Moreover, when it comes to a simple rectangular tall building, the flow is separated from the windward side edges of the building which led to shear layers with increasing wind velocities (Stathopoulos and Blocken, 2016) (Fig. 1). The possible magnitudes of the two driving forces (wind and buoyancy pressures) are also greater in designing the envelope and its openings, and these forces can lead to high wind speeds and unstable wind conditions. Due to all of these reasons, achieving a completely naturally ventilated tall building is a challenge.

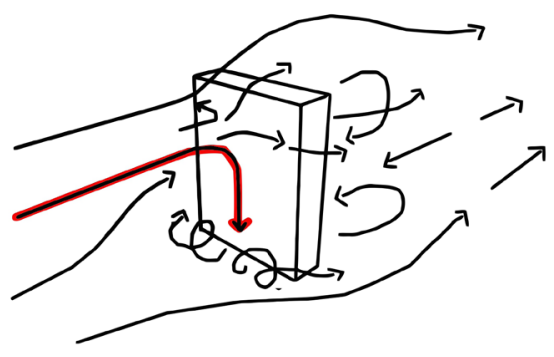

Fig. 1 An illustration of typical airflow conditions around a rectangular building (drawn by the author). 
Architectural aerodynamics is particularly more important when turbulent strong wind conditions exist. Natural ventilation is mostly regarded as a low-tech, passive system to condition a building, however due to the aerodynamic challenges, to control and monitor a tall building, BMS is required. At this point, a mixed-mode natural ventilation system switching between passive and active modes is a practical solution. In a tall building utilizing mixed-mode system, internal environmental conditions and external conditions of air temperature, humidity, wind speed, and rain are often measured with sensors. Then, BMS uses this information to alternate between passive and active modes. However, BMS will need to be dynamically adapted to climate variations and occupant behavior with the use of an advanced control system. Although the automatic control can provide the optimum comfort, giving manual control opportunity to the occupants will make improvements on user satisfaction. However, care must be taken that the actions of occupants do not change the system strategy. Therefore, users need to be aware of how to operate the sub-systems located in their room. An intelligent control panel, in most cases, can inform users which mode the building is operating in and the overall system strategy. On the other hand, a default system utilizing natural ventilation mode with a user override may ensure a well-balanced system for low energy use and improved occupant comfort. Improving the energy performance of a building with reducing the dependency of mechanical systems is, of course, a key role for natural ventilation, however, the integration with BMS opens the opportunity of improving both indoor air quality and thermal comfort conditions for users. In addition, the use of natural ventilation in an office environment provides a healthier and more comfortable environment for occupants and enhances their productivity and thus can help to solve health problems like sick building syndrome and noise-related mostly with mechanical systems. Moreover, there are several tall buildings relying on natural ventilation systems and mixed-mode systems (using both natural ventilation and mechanical system) illustrating improvements on employee productivity up to 18 percent, annually (Loftness, 2005). Furthermore, the use of natural ventilation potentially reduces the embodied energy, capital, maintenance, and operational costs of mechanical systems and the area needed for the mechanical systems (Wood and Salib, 2012).

\section{The fundamentals of natural ventilation}

In a tall building, the driving forces for natural ventilation are of course the same as those for other buildings. The physical mechanism for natural ventilation depends on the differences in pressure developed across the openings of a building envelope. The pressure differences occur due to:

- the effects of wind,

- temperature differences between inlet and outlet of air, or

- a combination of both.

Therefore, natural ventilation can be divided into two sub-categories as "wind-induced" and "buoyancy-induced" ventilation according to the physical mechanism driving the air. The former is developed if wind creates a pressure distribution around a building with respect to the atmospheric pressure. The pressure differences drive air into the building's envelope on the windward side (positive pressure zone) and out of the building through the openings on the leeward side (negative pressure zone). The pressure effect of the wind on a building is primarily dominated by the building's shape, the wind direction and velocity, and the influence of the surroundings, which are all factors that influence the pressure coefficient. In addition to the value of the pressure coefficient, the mean pressure difference across a building's envelope is dependent upon the mean wind velocity at upwind building height, and the indoor air density as a function of atmospheric pressure, temperature, and humidity (Wood and Salib, 2012).

In the wind tunnel practice on building aerodynamics, the CAARC (Commonwealth Advisory Aeronautical Council) tall building model is usually adopted to calibrate experimental techniques (Braun and Awruch, 2009). The full-scale dimensions of the building model are as follows: height $(H)=180 \mathrm{~m}$; length $(L)=30 \mathrm{~m}$; width $(W)=45 \mathrm{~m}$. The pressure distribution around this CAARC tall building model is illustrated in Fig. 2.

The density differences caused by variations in temperature and height between the inside and the outside or between certain zones within a building causes the other physical mechanism of natural ventilation: buoyancy-induced ventilation. This mechanism primarily relies on the height difference between air intake and extract openings and the air density difference resulting from temperature and moisture content in the air. To ensure inward air-flow in the absence of wind, the outdoor temperatures should be lower than the indoor temperatures. As the 

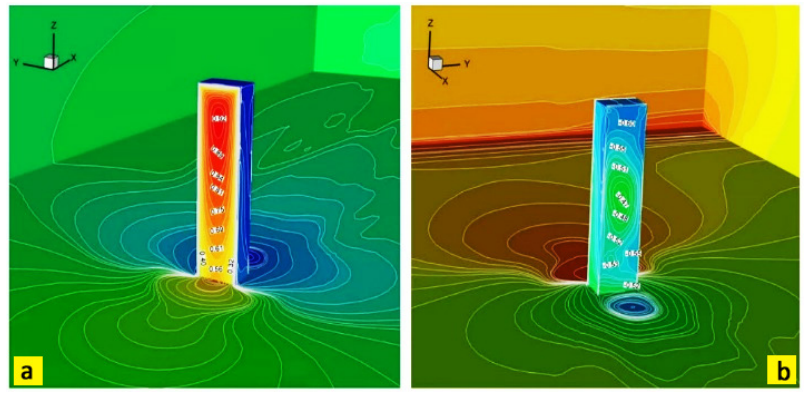

Fig. 2 Distribution of mean pressure coefficient over the building walls at the windward side (a); and the leeward side (b)

(Braun and Awruch, 2009).

indoor air temperature exceeds the outdoor temperature, an under-pressure is developed in the lower part of a building which pulls air inwards through the envelope openings. When the air passes through the building, it is heated by the internal gains and the occupants of the building. The variation in density caused by the difference in indoor and outdoor temperature results in a pressure gradient in the building. Since air flows from areas of high pressure to areas of low pressure, the over-pressured areas at the top of the building push air out of the openings in the envelope. However, at a certain height from the ground level, the indoor pressure and the outdoor pressure get equal. This certain level is named as the "neutral plane" or "neutral pressure level" (Fig. 3). To achieve effective buoyancy-induced ventilation, a minimal internal resistance to air movement within the interior spaces is required or a significant temperature differential between the inlet and outlet of air should occur. So, when floor plates cover the whole floor area without significant voids or atria,

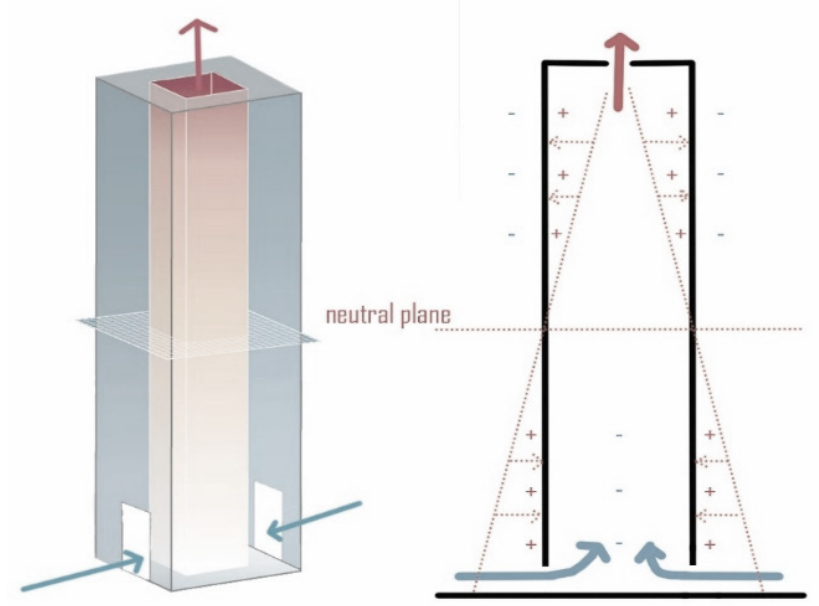

Fig. 3 Illustration of buoyancy induced ventilation in the absence of the wind for a rectangular tall building (drawn by the author). there will be no significant pressure buildup over the height of the building. On the other hand, a "reverse stack effect" may be formed if outdoor temperatures are considerably higher than the indoor temperatures. Air can enter high-rise buildings at higher levels under this condition and discharge at lower levels. It can be difficult to manage this reverse stack effect.

Last, the two driving mechanisms for natural ventilation (wind and buoyancy) may develop separately, however, in many cases, they occur at the same time. Thermal buoyancy will be the dominant driving force on a calm day with basically no wind, while wind-generated pressure differentials will usually be the dominant driving force on a windy day (Wood and Salib, 2012).

\subsection{Types of natural ventilation}

A ventilation system basically defines how air is pulled into the building and how it is exhausted. As in low-rise buildings, there exist three main types of natural ventilation in tall buildings:

- "Single-sided ventilation, where fresh air enters the room through the opening on the same side it is exhausted from. This strategy can ventilate the space effectively if the room depth is a maximum of 2.5 times its height. The driving force for single-sided ventilation is wind coinciding with the temperature difference between low-level air inlets and high-level air outlets. The buoyancy effect can also aid single-sided ventilation if the ventilation openings are located at different heights.

- Cross-ventilation, which relies on the flow of air between the two sides of a building's envelope due to the pressure differentials between openings in the two sides (air moves from the windward to the leeward side). For effective cross-ventilation, the depth of the room must not exceed five times its height. The buoyancy effect can also aid the effectiveness of cross-ventilation when the spaces are facing a tall open space such as an atrium.

- Stack-ventilation, which involves the entry of fresh air into the building at a low level and its exhaust at a high level due to the occurrence of temperature, density, and pressure differences between the interior and exterior or between certain zones within a building. Stack-ventilation is often used in buildings which have a central atrium, chimney, or elevated part" (Wood and Salib, 2012:p.19). 


\subsection{Mixed-mode ventilation}

The local site and extreme climatic conditions may prevent depending entirely on natural ventilation. Using natural ventilation may not be suitable for buildings in extremely cold, hot, and/or humid) climates or on local sites with high levels of noise and air pollution. At this point, mixed-mode or "hybrid" ventilation ensures an appropriate system that uses a combination of natural ventilation (from operable windows and/or vents) and mechanical systems to provide both cooling and air distribution. In general, mixedmode buildings are categorized based on their operation strategies, which illustrate whether natural ventilation and mechanical cooling are operating in the same or different spaces in a building, and/or at the same or different times (Wood and Salib, 2012). According to Brager et al. (2000), mixed-mode ventilation strategies are typically classified into the following categories:

- "Contingency, where the building is designed either as an air-conditioned building with provision to switch to natural ventilation or as a naturally ventilated building with space and electrical infrastructure allocated for the possible installation of mechanical equipment for air-conditioning in the future.

- Zoned, where mechanical cooling and natural ventilation operate in different areas or zones of the building.

- Complementary, where the building is designed with the capability to operate under mechanical and natural ventilation modes in the same space. This category is further subdivided into Alternate, Changeover, and Concurrent mixed-mode strategies as described below:

- Alternate, where the building includes provisions and equipment for both air-conditioning and natural ventilation but operates continuously in one mode or the other.

- Changeover, where the building switches between mechanical cooling and natural ventilation on a seasonal or daily basis, depending on the outside weather conditions.

- Concurrent, where mechanical cooling and natural ventilation can operate in the same space at the same time (e.g., when an HVAC system supplements natural ventilation to extend occupant comfort and maximize energy efficiency)" (Etheridge and Ford, 2008:p.20).

Last, it should be noted mixed-mode buildings mostly incorporate complex Building Management Systems and control strategies to overlap/alternate between the natural ventilation and mechanical systems.

\section{Case studies}

A number of tall buildings having an efficient natural ventilation strategy combined with BMS are given in the following parts. The performance of the natural ventilation strategy implemented and its interface with the central Building Management System was the main criteria when deciding on the case studies. Within this scope, RWE Headquarters Tower, GSW World Trade Center and KfW Westerkade are presented.

\subsection{RWE Headquarters Tower}

RWE Headquarters Tower (1996) with a height of 127-meter is one of the first examples of sustainable tall buildings. It has a double-skin glass envelope to ensure natural ventilation to the perimeter office spaces. The building freely stands behind a perimeter block in downtown Essen, Germany (Fig. 4). It has a circular plan with a central service and circulation core, and the office spaces located along its perimeter (Fig. 5). With the office spaces located along the building perimeter, access to daylight and natural ventilation are

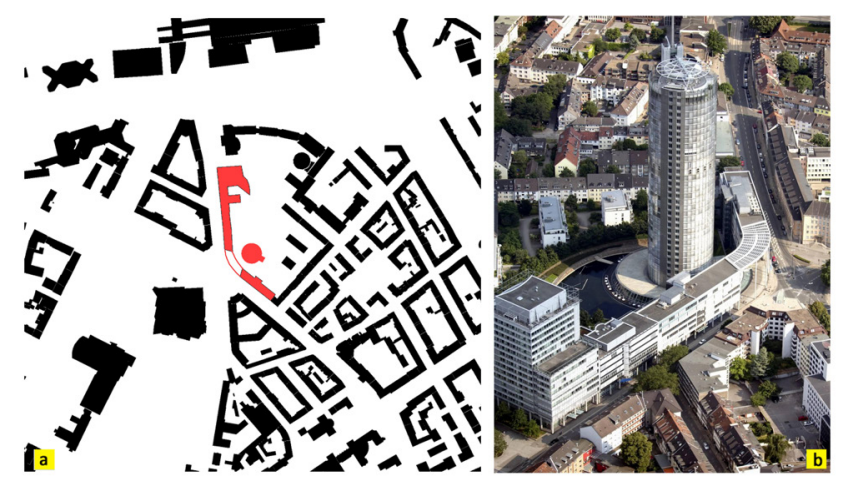

Fig. 4 RWE Headquarters Tower, site plan(a); and overall view (b) (C) Ingenhoven Architects.
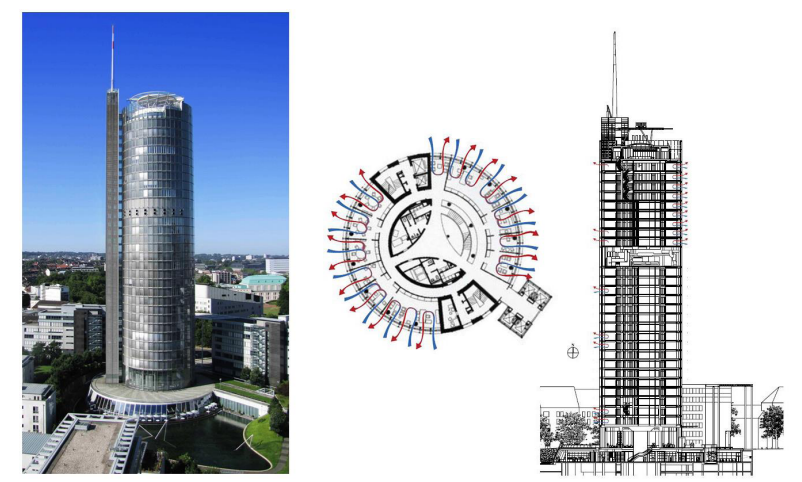

Fig. 5 RWE Headquarters Tower, plan and section drawings. 
maximized. Elevators are mostly detached from the office space in a separate form and attached to the southeast side of the tower to create an open central space free of obstructions. A double-height floor accommodating the mechanical systems is placed on level 19 (Wood and Salib, 2012).

The double-skin façade with a $500 \mathrm{~mm}$ air cavity consists of extra-clear toughened exterior glass panels of 2 meters width by 3.5 height. The inner side of the double-skin façade features floor-to-ceiling sash windows with fixed and sliding glass panels which can be opened up to approximately $150 \mathrm{~mm}$ with a winding handle. The intermediate air cavity is segmented vertically at each floor by a "Fish Mouth" device and horizontally with a glass panel to provide acoustic insulation and to enhance natural ventilation (Fig. 6). The Fish Mouth device is designed specifically for fresh air intake and exhaust, vertical sound transmission control, and façade outer skin support. The Fish Mouth, in combination with the double-skin façade, is a key component of the natural ventilation system of the building (Wood and Salib, 2012).

The Fish Mouth device actually has two types; one type releases air into the cavity of the façade while the other exhausts fresh air (Fig. 7). Each double-skin module has only one form of Fish Mouth device. Therefore, each façade module alternates across the envelope,
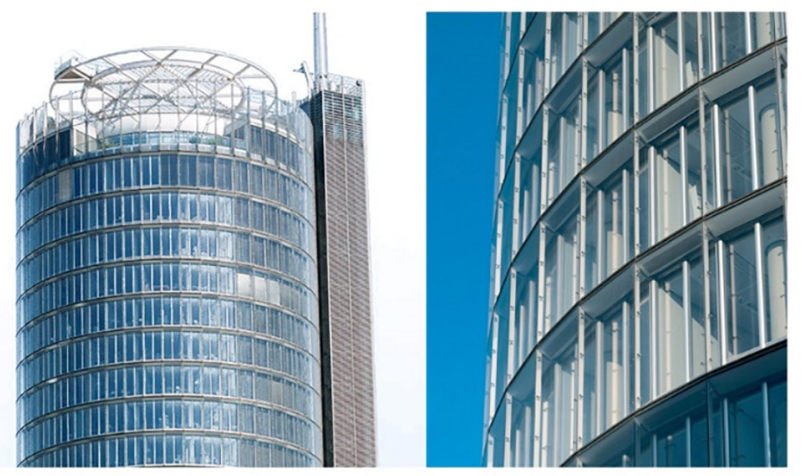

Fig. 6 RWE Headquarters Tower, close views from the double-skin façade.
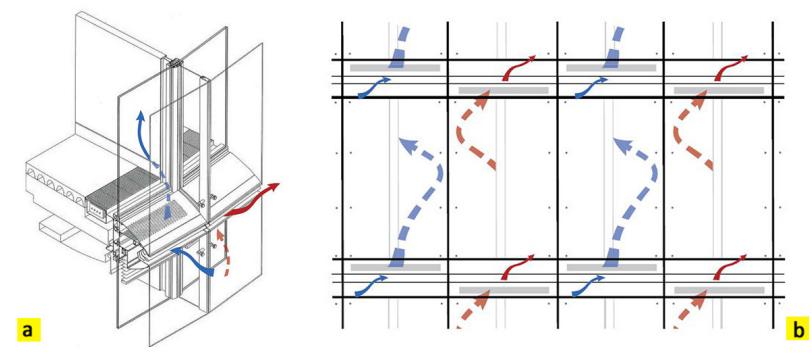

Fig. 7 Isometric drawing of the double-skin façade illustrating the Fish Mouth device (a); and façade elevation showing the alternating system of the inlet and outlet modules (b) (C) Ingenhoven architects. ensuring even the smallest office to have both devices. These modules are divided by vertical glass panels to prevent exhausted air from re-entering the adjacent façade cavity and short-circuiting issues where fresh air would exit the cavity without ventilating the spaces entirely. Another feature of the device is to adjust the air velocity by making it slower or faster by considering the exterior wind velocity and required air change rates. As wind velocity increases at higher altitudes, to moderate wind pressures alongside the envelope, Fish Mouth devices have two opening sizes (one size for above floor 16 and one for below). Furthermore, the tapered shape of the device with curved reflective surfaces also maximizes the admittance of natural light by approximately 20 percent. As Evans (1997) states CFD simulations and largescale wind tunnel tests were used to optimize the design, form, and opening sizes of these devices.

The indoor environment is consistently regulated through the central BMS, which gathers data from the sensors located in each space and on the façade (Pepchinski, 1997). The BMS also controls the blinds in the cavity, adjusts the ventilation openings, and switches to the mechanical ventilation system especially in extreme wind speeds (such as $7 \mathrm{~m} / \mathrm{s}$ below floor 16 and $10 \mathrm{~m} / \mathrm{s}$ above). In such conditions, the BMS closes ventilation openings at the envelope and turns the mechanical ventilation system on. Reversely, if a window is opened in favorable weather conditions, the BMS switches off the convector in the specific room with the open window. Even though the BMS has automatic modes, users of the building have a high level of control over their environment. For instance, each room has a minimum of two sliding windows which can be manually controlled by the occupants. Furthermore, by using the control panel next to each office door (Fig. 8), occupants can override the BMS. They can change the temperature up to a three-degree variation from the rest of the building and the illumination level
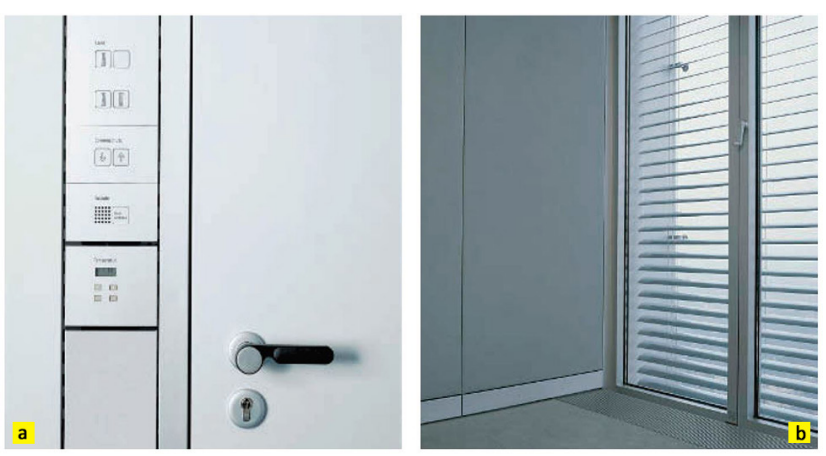

Fig. 8 The control panel next to office doors (a) and an interior view showing perforated aluminum blinds in the façade cavity (b) (C) Ingenhoven architects. 
through automatically controlled blinds in the double skin façade cavity (Wood and Salib, 2012).

The RWE Headquarters Tower can utilize natural ventilation throughout the $75 \%$ of a year. However, the amount of the savings per year due to using the natural ventilation strategies is not known since it is not published (Wood and Salib, 2012).

\subsection{GSW Headquarters Tower}

This building is an extension of an existing office tower which was built in the 1950s as one of the first projects during the reconstruction of Berlin. The project attempts to merge the city's "lost" fragments and assemble them into a three-dimensional structure that reintegrates the existing building into its context. In the western façade, solar shading systems are colored in red and pink shades to give the tower an identity thus separating it from the elements of the current ensemble (Fig. 9). The GSW Tower primarily formed with a slightly curved arc in plan (Fig. 10). Even though the narrow, linear plan, it covers a variety of office spaces (Wood and Salib, 2012).

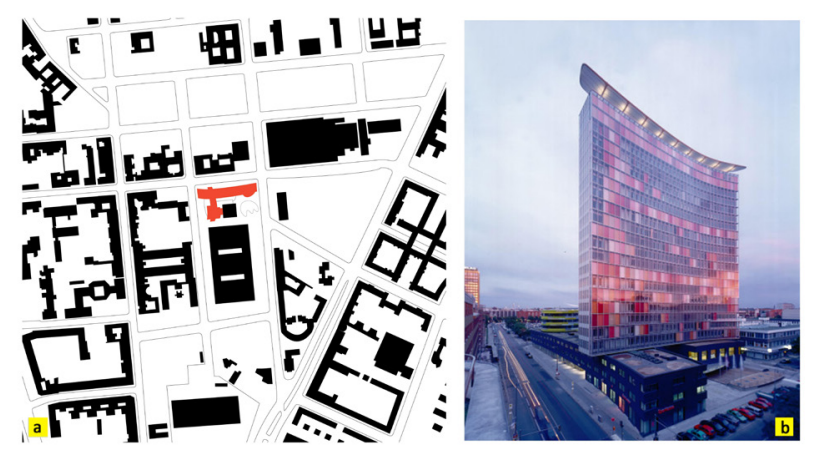

Fig. 9 GSW Headquarters Tower, site plan (a); and overall view (b) (c) Sauerbruch Hutton.
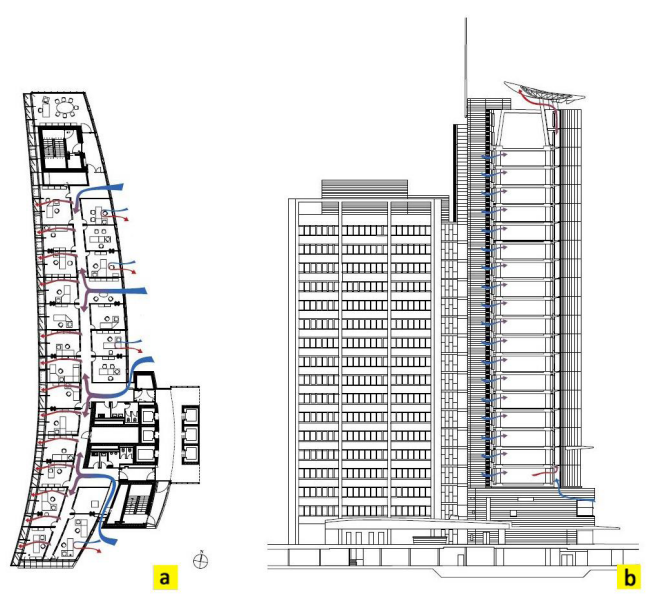

Fig. 10 GSW Headquarters Tower, plan (a); and section (b) (c) Sauerbruch Hutton.
A key element of the natural ventilation strategy is the double-skin façades along the east and west elevations of the tower. The western façade's double-skin system consists of an external single-glazed weather screen and an internal double-glazed window enclosing a cavity of one-meter depth. In every second bay of the façade, the inner windows can be opened to allow air from the offices to flow into this intermediate space that acts as a "thermal flue". The east façade's double-skin system consists of a $200 \mathrm{~mm}$ cavity and an outer skin alternating between single-glazed window panels and fixed louvered screens allowing fresh air to enter the cavity (Fig. 11). The inner layer of the east façade comprises double-glazed window panels that combine with a pivoting panel (located directly behind the louvered screen) which allows fresh air to flow into the interior. Flexibility in office configurations is exposed by the asymmetric layout of the air intake louvers on the east façade, where distribution reflects a clear relation to the building's design and spatial articulation since managed and measured air volume flow rates were to be determined to prevent excessive drafts, etc. The window openings are arranged according to the configuration of each floor plan. If plan layouts are required to be changed, these openings can be adjusted to maintain the same air change rates in all offices (Wood and Salib, 2012).

For each floor individually, the natural ventilation concept in the GSW Tower can be defined as cross-ventilation, while the overall strategy relies on stack ventilation to force exhaust air out of the tower. Fresh air reaches the building through the eastern façade, then it passes through the western façade's "thermal flue", last it is ultimately released to the outdoor environment at the roof level. However, numerous natural ventilation strategies were planned for different plan configurations. For instance, cross-ventilation is induced from the ventilation openings (with sound-absorbent lining) on the top of the partition walls of offices. As the air passes through each floor, these

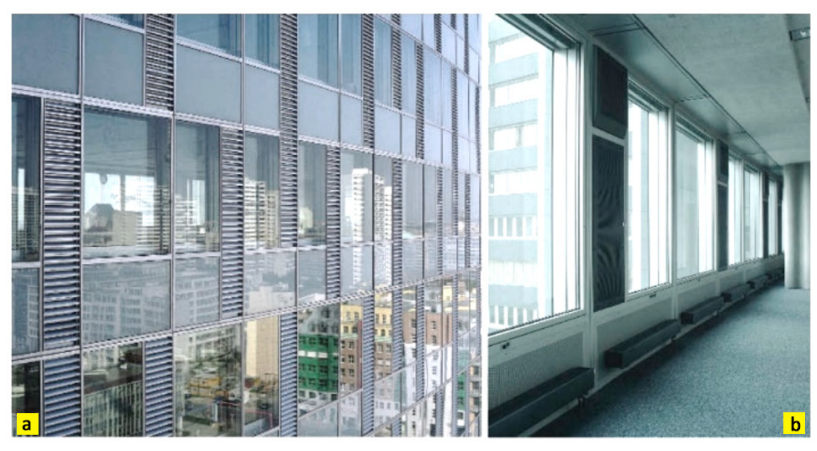

Fig. 11 Louvered air intake openings on the east façade (a); and the inner upper panels which pivot downward for air intake (b) (C) Annette Kisling. 
acoustically insulated openings allow the air to enter all the offices. As the air travels through the offices, it is pull out via the operable windows on the west façade into the "thermal flue", which is continuous up the building height. Then the accumulated heat due to the sun and the internal heat gains of offices are extracted via stack effect. Consequently, this buoyancy induced ventilation in the western double-skin façade results in a negative pressure which facilitates the cooler fresh air entrance from the east façade. However, the windows on the two façades should be open to achieve both the stack effect and the cross-ventilation at the same time (Fig. 12) (Wood and Salib, 2012).

An important feature of the natural ventilation system is the "Wing Roof" which is directly above the thermal flue (Fig. 13). The wind passing through the area between the thermal flue and wing roof is accelerated passively. This acceleration increases the negative pressure in the thermal flue and induces stack effect via ensuring extra uplift for air in the thermal flue. However, if the wind is blowing from the reverse directions, a number of flaps suspended from the wing roof works as an obstruction for the wind to create small scale vortexes (eddies). This is an important planning feature to avoid the risk of positive pressure build-up and the occurrence of down flows over the outlet of the flue (Wood and Salib, 2012).

The entire tower is planned to run on natural ventilation completely if outdoor temperatures are in the range

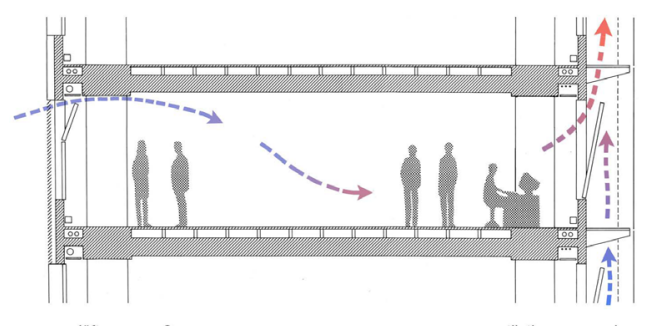

Fig. 12 GSW Headquarters Tower, cross ventilation strategy, (C) Sauerbruch Hutton.
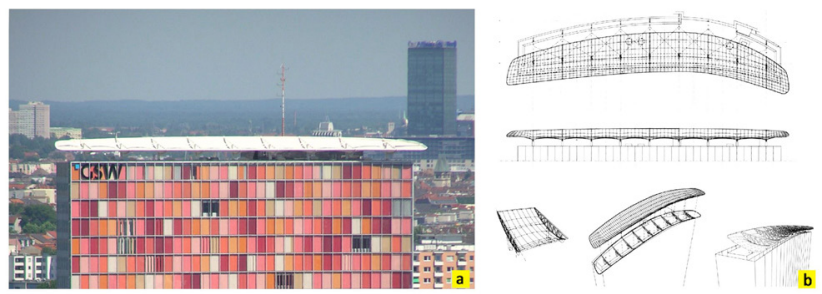

Fig. 13 GSW Headquarters Tower, overall view of the wing roof (a) and detailed drawings of the roof (b) (C) Sauerbruch Hutton. of $5-25{ }^{\circ} \mathrm{C}$. Mechanical ventilation system is only activated by the BMS if the outdoor temperature drops below $5{ }^{\circ} \mathrm{C}$ or rises above $25^{\circ} \mathrm{C}$. The BMS also changes the location of the dampers at the top and bottom of the thermal flue (Fig. 14), which controls the airflow from the building into the flue and within the flue, depending on the external environment. The BMS collects data from an external weather station and from sensors that spread evenly across the east and west façade, and inside the thermal flue. Those sensors track the temperature, pressure and wind speed. The BMS indicates depending on the data, whether mechanical or natural ventilation is suggested to users through the display of red or green lights on each office module's window casement. Additionally, a wallmounted zone controller enables users to either mechanically or naturally ventilate separate zones within a floor. The BMS also controls the transmission of daylight and heat into the interior by the operation of the moveable solar shading devices inside the flue of the west façade (vibrantly colored on the outward-facing side, adding character to the building façade) and Venetian blinds located inside the east façade's cavity. The blinds are enabled automatically to prevent overheating in the morning or afternoon by controlling heat transmission. On the other hand, when the blinds are open and daylight illumination is sufficient, through the use of light sensors inside the façade, the row of electric lights adjacent to the windows are switched off. Even though the utilization of automatic control modes, users can manually override the BMS's control of the blinds and the automated daylight-linked switching (Wood and Salib, 2012).

The GSW Headquarters Tower can utilize natural ventilation throughout the $70 \%$ of a year. The amount of the savings per year for heating and cooling due to using the natural ventilation strategies is $53 \%$ compared to a fully air-conditioned German office building (estimated) (Wood and Salib, 2012).

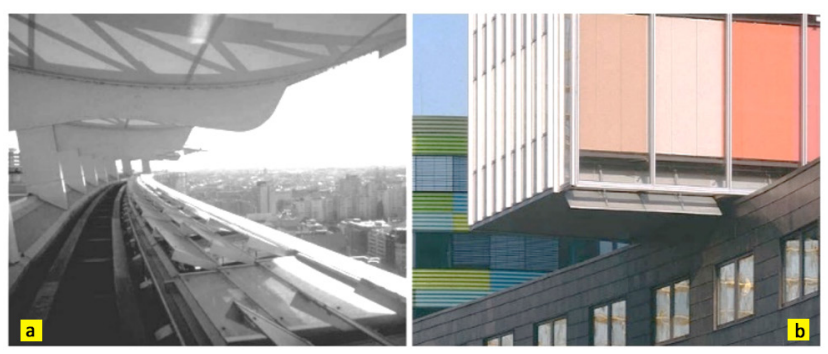

Fig. 14 Dampers located at the top of the thermal flue (a) (C) Arup and Dampers located at the bottom of the thermal flue (b) (C) Annette Kisling. 


\subsection{KfW Westarkade}

KfW Westarkade was built as an extension to the KfW Bankengruppe Headquarters complex to ensure extra office space. The tower was designed in a streamlined form (Fig. 15) to respond to the direction of prevailing wind and the sun path. The tower rests on a curved four-story podium which has a number of connections on multiple levels to the adjacent existing KfW buildings. Additionally, by defining a street edge and creating a courtyard that flows into the adjacent public park, the podium is integrated with its immediate environment (Sauerbruch, 2011).

The podium houses a reception foyer, a conference center, and cellular offices. The tower's central service core includes a vertical circulation, toilets, and service amenities. A corridor, which surrounds the central core, provides access to the cellular offices located alongside the perimeter of the tower (Fig. 16). This layout ensures all the offices to have access to natural ventilation and daylight.

The cellular offices, located along the perimeter of the tower, are naturally ventilated with a double-skin façade which is continuous through the entire envelope and is segmented at each floor. The outer component of the double-skin façade has a sawtooth form alternating with slender colored glass panels and fixed glass panels (Fig. 17). There is an acoustic insulation between the fixed panel and the colored operable panels which can open up to $90^{\circ}$ (side-hung), drawing fresh air into the air cavity of the double skin façade (Sauerbruch, 2011).

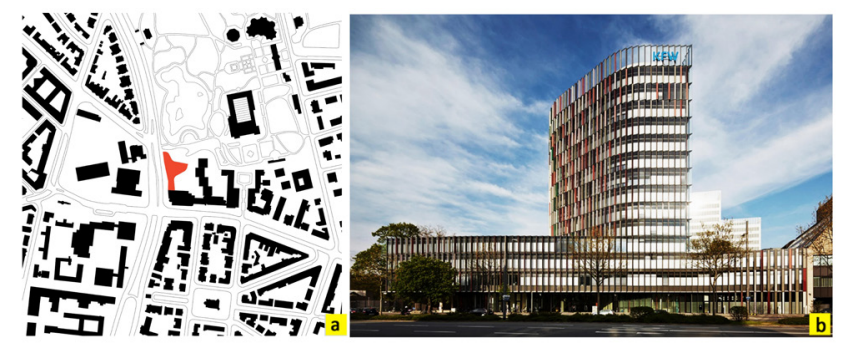

Fig. 15 KfW Westarkade, site plane (a); and overall view (b) (c) Sauerbruch Hutton.
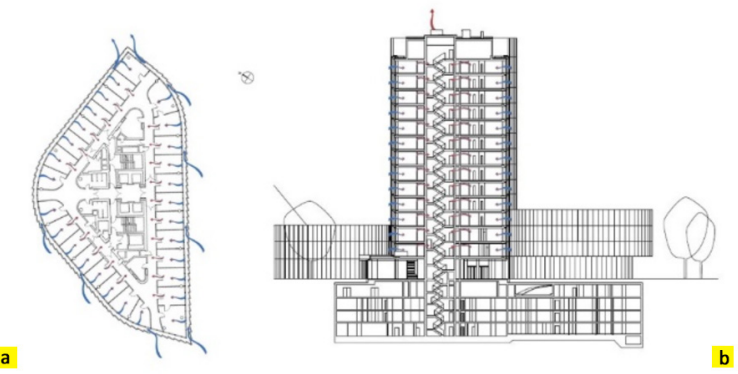

Fig. $16 \mathrm{KfW}$ Westarkade, plan (a); and section (b).

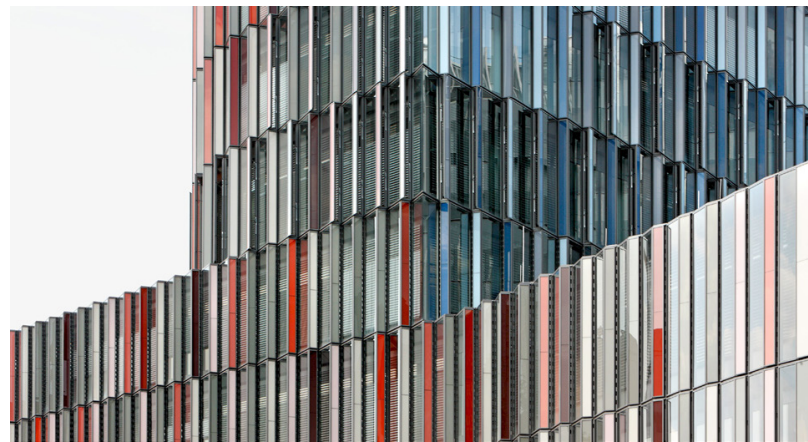

Fig. 17 Sawtooth profile façade with slender colored panels between larger fixed glass panels (C) Jan Bitter.

The inner component of the double skin facade also alternates between operable and fixed modules. There is a $700 \mathrm{~mm}$ air cavity between the outer and inner layers of the façade, and this zone is continuous along the entire building perimeter (Figs. 18 and 19) in horizontal direction. Moreover, this zone is partitioned with steel sheeting at each floor level to provide protection against
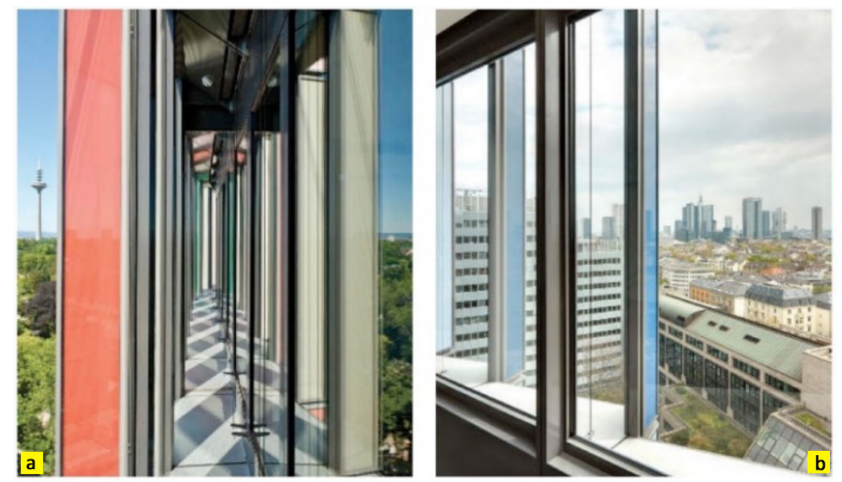

Fig. 18 View into the $700 \mathrm{~mm}$ continuous horizontal cavity of the double skin (a) C KfW-Bildarchiv/Thomas Klewar; Double-skin façade viewed from interior showing the colored glass panels that open by pivoting outwards (b) C Jan Bitter.
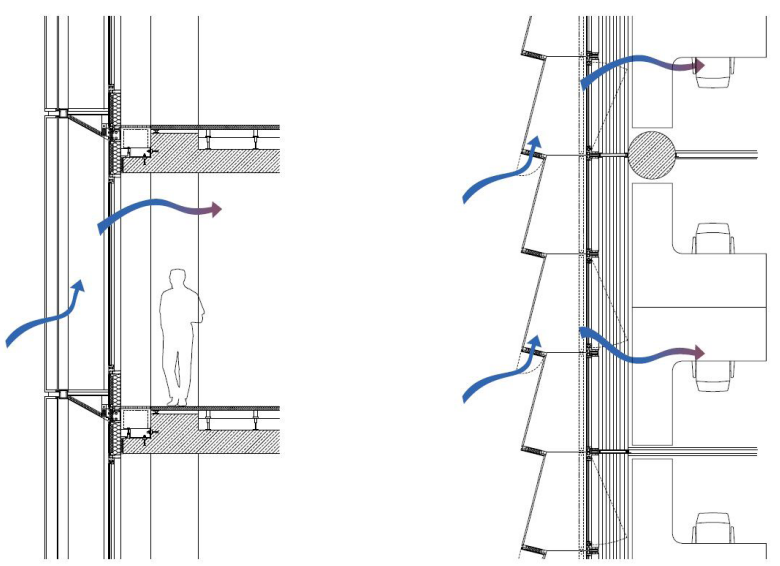

Fig. 19 Detailed section through the double-skin façade (a), detailed plan through the double-skin façade (b) C Sauerbruch Hutton. 
fire. Smoke barriers can divide the air cavity into three sub-fire-protection volumes that are analogous to the fire-protection zones of each floor. The sawtooth form of the exterior façade and the absorptive aluminum sheeting positioned below and above the steel sheeting (vertically segments the façade cavity) prevent interior sound transmission between the offices (Fig. 18) (Meyer, 2011).

The colored panels of the outer skin are opened to draw fresh air into the air cavity. Then, through the operable windows on the inner side of the façade this fresh air enters the offices (Fig. 19). Based on the wind conditions and outdoor temperature, the panels are opened automatically providing that pressure and temperature conditions remain consistent in the air cavity. The exterior façade can be opened entirely on warm summer days to prevent overheating with allowing wind to flow through all the air cavity. On cooler days, to avoid heat loss, a minimal number of vents are opened (Wood and Salib, 2012).

Another feature of the double-skin façade is the air cavity which is also called as the "Pressure Ring". This inner zone maintains a stable positive pressure around the tower (Fig. 20). The orientation and operation of the colored flaps are a key component to ensure this consistent pressure. These flaps are controlled and monitored by the BMS. A commonly seen issue in natural ventilation systems is the differences in the pressure between the windward and leeward sides of the building that can easily lead to excessive strong airflow. To cover the tower against extreme wind speeds and to create a constant controlled flow of air into the offices, the pressure ring plays a key role. This constant pressure zone allows occupants to manually operate the windows across the year without drafts or heat loss. Thus, the ventilation of the offices is provided naturally with minimal reliance on outdoor conditions (Wood and Salib, 2012). While the air passes across the offices, it is subsequently exhausted to the negatively pressurized zones enclosing the offices. Then, via the central vertical shaft (service core) air extracted through slots on the core walls just below the ceiling level, and last exhausted air is vented through the roof openings (Fig. 21). However, wind speeds should
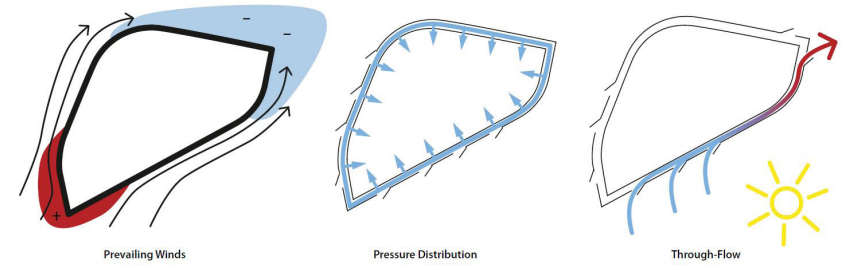

Fig. 20 Diagrams of the Pressure Ring façade (C) Sauerbruch Hutton.

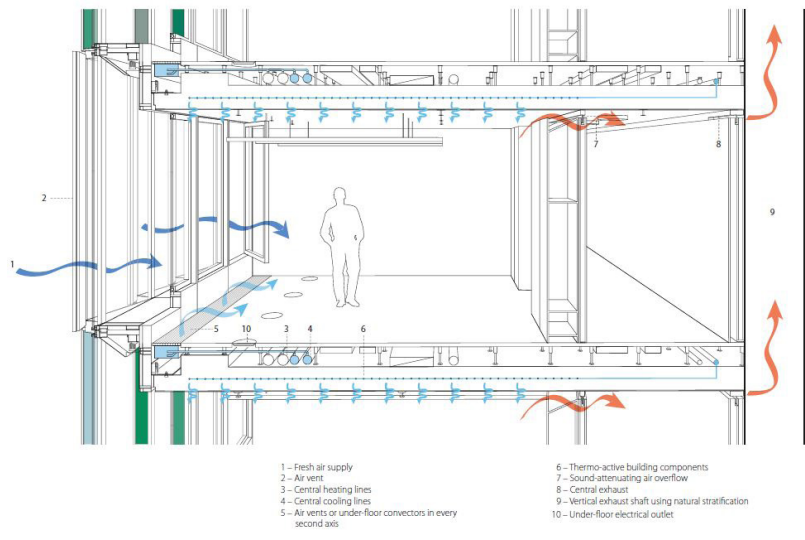

Fig. 21 Detailed section of typical office ventilation (C) Sauerbruch Hutton.

induce enough negative pressure at the roof level to drive air upwards through stratification. Therefore, mechanical ventilation is used to exhaust the air from the cores when the wind speeds are low. During winter, when heat-recovery is used, mechanical ventilation is activated and a by-pass fin is opened to draw warm exhaust air back to the HVAC center for recycling purposes (Wood and Salib, 2012).

The tower accommodates a weather station at the roof to monitor the wind direction, pressure, wind speed, outdoor temperature and daylight levels. Based on these data, the Building Management System controls the ventilation fins at the outer side of the façade to draw fresh air into the air cavity in the façade and consequently into the interior spaces. On the other hand, ventilation fins are not always at the same position, therefore they can be adjusted to fit for numerous settings. For instance, the fins can be adjusted anywhere from fully open at $90^{\circ}$ to the closed (Fig. 22). The positioning of the flaps generally depend on the climatic conditions as well as on the number of windows opened on the inner façade; it is dynamically managed to fulfill an equal amount of pressure inside the pressure ring.

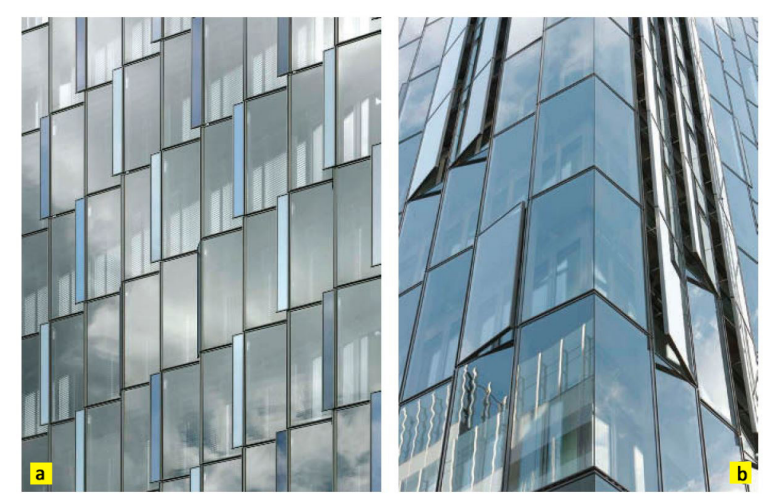

Fig. 22 Façade detail showing flaps letting air into the façade cavity (a); flaps opened at the "tip" to enable through-flow of air (b) (C) Jan Bitter. 
In other words, in order to create a volume of stable positive pressure within the building's inner skin, the BMS controls the specific operation of the fins, while concurrently ensuring a slight pressure difference between the air cavity and the interior to maintain inward flow of air (Gonchar, 2010). The wind speed inside the Pressure Ring is regulated as it cannot exceed $6 \mathrm{~m} / \mathrm{s}$. Furthermore, the outdoor temperature is also an input parameter to decide on the operation of the fins. For instance, to avoid overheating, the fins are mostly opened fully in the summer whereas to allow the double-skin façade to work as a solar collector, they are opened minimally in the winter. In addition, to avoid excessive heat gain in summer, the entire flaps at the tip of the building can be opened to allow through-flow of the air (Fig. 22). Last, across the year, the BMS will inform occupants whether or not to open the windows in their immediate environment via an LED screen, but it will provide the occupant the final decision (Wood and Salib, 2012).

The KfW Westarkade can utilize natural ventilation throughout the $60 \%$ of a year. The amount of the savings per year for heating and cooling due to using the natural ventilation strategies is $84 \%$ compared to a fully air-conditioned German office building (estimated) (Wood and Salib, 2012).

\section{Conclusion}

In this study, only a number of tall buildings using natural ventilation strategies with a Building Management System to enhance the overall energy performance of the building are presented. Throughout the study, it is not meant to be comprehensive, rather it is preferred to provide some perspectives from the view of architects in the context of sustainable smart buildings and cities.

It is indicated that natural ventilation plays a key role in providing both good indoor air quality and acceptable thermal comfort conditions for occupants and also reduces energy consumption due to the mechanical systems. In addition, natural ventilation in an office environment has the potential to eliminate noise and health problems associated with mechanical HVAC systems.

Moreover, it is seen that the important role of architectural and urban aerodynamics in designing buildings

\section{References}

Brager, G. S., Ring, E., Powell, K. (2000) "Mixed-mode ventilation: HVAC meets Mother Nature", eScholarship: Open Access Publications from the University of California. [online] Available at: https:// escholarship.org/uc/item/0285m0h1 [Accessed: 05 February 2020] to increase the effectiveness of natural ventilation systems is significant. Therefore, wind conditions that can change considerably depending on the building form are required to be thoroughly analyzed. It is clear that aerodynamically designing the building leads to improvement in natural ventilation, so preliminary comprehensive studies as to the airflow characteristics in and around building are very important for the efficiency of such systems.

Furthermore, it is also derived that when adopting natural ventilation systems in tall buildings, a number of challenges are faced. However, it is not primarily the turbulent strong wind conditions at the higher altitudes. As illustrated with a number of case studies it can be solved in so many ways. But beyond designing the most effective system for a particular site, program, building type, and configuration, perhaps the biggest challenge is overcoming the use of air-conditioning which has become the norm in modern buildings and carries a quality status related to its use. Overcoming this perceived quality barrier may open the way of 100 percent natural ventilation in tall buildings. Even though the energy reductions and cost benefits are considerable, there is still a perceived quality and reliability issues with natural ventilation. Hybrid buildings reduce operating energy for a portion of the year but do not eliminate the embodied energy that resides in the mechanical plant, nor the space needed to house such equipment. Therefore, the true potential of delivering ventilation by natural means will only be achieved through 100 percent reliance on natural ventilation and the consequential removal of mechanical plant. Of course, for extreme climate conditions, using a mechanical ventilation system as a back-up to natural ventilation is viable.

Last, as a further study, the performance of the natural ventilation systems presented here can be numerically and experimentally investigated. Although it is very probable to see that using a natural ventilation system leads to a significant decrease in energy consumption, a detailed simulation with computational fluid dynamics or an experimental study in a wind tunnel can be more explanatory and may open further perspectives in the way of achieving 100 percent reliance on natural ventilation.

Braun, A. L., Awruch, A. M. (2009) "Aerodynamic and aeroelastic analyses on the CAARC standard tall building model using numerical simulation", Computers \& Structures, 87(9-10), pp. 564-581. https://doi.org/10.1016/j.compstruc.2009.02.002 
Etheridge, D, Ford, B. (2008) "Natural ventilation of tall buildings Options and limitations", In: 8th World Congress - Tall and Green: Typology for a Sustainable Urban Future (CTBUH 2008), Dubai, United Arab Emirates, pp. 1-7.

Evans, B. (1997) "Through the glass cylinder", Architect's Journal, 205(19), pp. 42-45.

Loftness V. E. (2005) "Building Investment Decision Support (BIDSTM) cost-benefit tool to promote high performance components, flexible infrastructures \& systems integration for sustainable commercial buildings and productive organizations", The American Institute of Architects, Washington, DC, USA, pp. 12-31.

Gonchar, J. (2010) "More Than Skin Deep", Architectural Record, 198(7), pp. 102-110

Meyer, U. (2011) "Colors 'n curves: a new bank headquarters in Frankfurt may well be the world's most energy-efficient office tower - KFW Westarkade, Frankfurt, Germany", GreenSource Magazine, pp. 48-53.
Pepchinski, M. (1997) "RWE AG Hochhaus - Essen, Germany", Architectural Record, 185(6), pp. 144-151.

Sauerbruch, M. (2011) "Sustainable architecture", Detail Green English, 1, pp. 26-31.

Stathopoulos, T, Blocken, B. (2016) "Pedestrian Wind Environment Around Tall Buildings", In: Tamura, Y., Yoshie, R. (eds.) Advanced Environmental Wind Engineering, Springer, Tokyo, Japan, pp. 101-127.

https://doi.org/10.1007/978-4-431-55912-2_6

Wood, A., Salib, R. (eds.) (2012) "Guide to Natural Ventilation in High Rise Office Buildings", Routledge, London, UK. https://doi.org/10.4324/9780203720042 